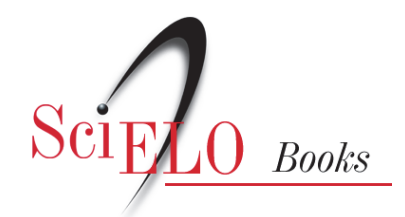

\author{
Erotismo e Religião: \\ cópula e comunhão na poesia de Hilda Hilst e Adélia Prado
}

Geruza Zelnys de Almeida

Cristiane Fernandes Leite

FERRAZ, S., et al.,orgs. Deuses em poéticas: estudos de literatura e teologia [online]. Belém: UEPA; Campina Grande: EDUEPB, 2008. 364 p. ISBN 978-85-7879-010-3. Available from SciELO Books $<\underline{\text { http://books.scielo.org }>\text {. }}$

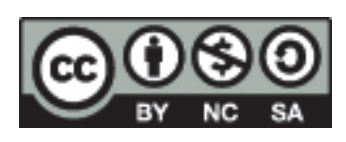

All the contents of this work, except where otherwise noted, is licensed under a Creative Commons Attribution-Non Commercial-ShareAlike 3.0 Unported.

Todo o conteúdo deste trabalho, exceto quando houver ressalva, é publicado sob a licença Creative Commons Atribuição Uso Não Comercial - Partilha nos Mesmos Termos 3.0 Não adaptada.

Todo el contenido de esta obra, excepto donde se indique lo contrario, está bajo licencia de la licencia Creative Commons Reconocimento-NoComercial-CompartirIgual 3.0 Unported. 


\section{Erotismo e Religião: cópula e comunhão na poesia de Hilda Hilst e Adélia Prado}

Geruza Zelnys de Almeida E Cristiane Fernandes Leite 


\section{sluctòs: osfigilsins omeitote}

9b. siegog, she obrimumos, 9

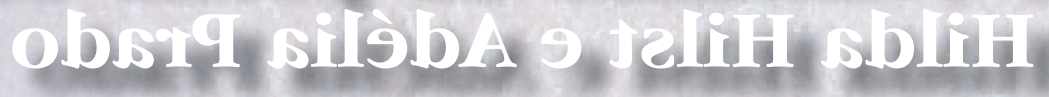

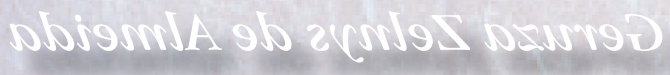

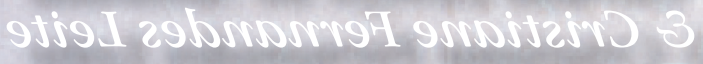


ALMEIDA, Geruza Zelnys de* LEITE, Cristiane Fernandes**

Resumo: $\mathrm{O}$ artigo reflete sobre a natureza ontológica das experiências erótica e religiosa na poesia de Hilda Hilst e Adélia Prado, analisando a busca pelo sagrado a partir de duas vias distintas: a cópula, em Hilda, e a comunhão, em Adélia.

Palavras-chave: Literatura, Teologia, Erotismo, Hilda Hilst, Adélia Prado.

Abstract: The article investigates the ontological nature of erotic and sacred experiences into the poetry of Hilda Hilst and Adélia Prado, analyzing how each author seeks the sacred along a different path: Hilda, in copulation; and Adélia, in communion.

Key-words: Literature, Theology, Eroticism, Hilda Hilst, Adélia Prado.

* Profa. Ms. em Literatura e Crítica Literária pela Pontifícia Universidade Católica de São Paulo (PUC/SP), Departamento de Literatura e Crítica Literária, e-mail: zelnys@hotmail. com

** Profa. Ms. em Literatura e Crítica Literária pela Pontifícia Universidade Católica de São Paulo (PUC/SP), Departamento de Literatura e Crítica Literária, e-mail: cftavares@ hotmail.com 


\section{Cópula \& Comunhão}

O sentimento religioso e o sentimento erótico são frutos do desejo de união, de completude o que, de certa forma, tem relação direta com a busca pelo transbordamento, pelo arrebatamento, pela sensação indizível de intenso prazer e gozo: o êxtase, muitas vezes identificado com a morte. Sendo assim, erotismo e religião estão intimamente ligados à criação poética, já que são experiências ontológicas que se fazem presentes através do poema (transcendência) e pelo poema (imanência), inscrevendo-se na própria estrutura, apreendida logicamente no corpo poético. Assim cópula e comunhão serão analisadas como as duas faces - proibição e transgressão - do elemento sagrado.

\section{Do erotismo: Hilda Hilst e a cópula imagética}

Na poesia de Hilda Hilst, Deus é a grande busca, mas a tentativa de materializá-lo por meio da palavra poética coloca a autora frente a uma impossibilidade devido ao fracasso da língua para dizer e/ou presentificar o todo. Em luta contra a falibilidade sígnica, Hilda chega às últimas conseqüências mergulhando no sensível para encontrar o incognoscível por meio da 'sensualização' da forma (o movimento erotizante do pensamento), da cópula imagética, ou ainda, da pornografia vernacular. Assim, para chegar até o Deus desejado, a poeta busca, sobretudo, a morte, estado limítrofe entre corpo e espírito, abismo entre o ser desejoso e o desejado, procurando conhecê-la em sua singularidade, ou seja, na inscrição do próprio nome.

Octávio Paz, em $O$ arco e a lira, afirma que "a primeira coisa que o homem faz diante de uma realidade desconhecida é nomeá-la, batizá-la [porque] aquilo que ignoramos é o inominado" (1982, p. 37). Portanto, se nomear é conhecer, o nomeado, quando se mantém desconhecido ou inalcançável, reclama uma re-nomeação, nem que seja, ao menos, para criar uma ilusão de conhecimento que satisfaça o intelecto. Por isso, Hilda tece infinitos nomes à procura da imagem/idéia inaugural, que a aproxime do ser morte, numa tentativa de conhecer o símbolo pela forma como se indicia.

Esse procedimento desemboca numa espécie de ritual de cópula imagética, ou seja, o movimento frenético das imagens funde-as num todo prenhe de significação. Está aí a natureza erótica da poética hilstiana, uma vez que a busca do erotismo é a fusão e, segundo Bataille, 
citado em O corpo impossível por Eliane Robert Moraes, a eliminação dos limites que viola as identidades e possibilita a total comunhão entre um e outro ser $(2002$, p. 50$)$.

Observa-se esse procedimento, por exemplo, em Da morte. Odes Mínimas. (2003), tortuoso monólogo poético - composto de quarenta poemas - que o eu-lírico dirige à Morte:

"Te batizar de novo.

Te nomear num trançado de teias

E ao invés de Morte

Te chamar Insana

Fulva

Feixe de Flautas

Calha

Candeia

Palma, por que não?

Te recriar nuns arco-íris

Da alma, nuns possíveis

Construir teu nome

E cantar teus nomes perecíveis:

Palha

Corça

Nula

Praia

Por que não?" (I, p. 29)

Insatisfeita com a idéia de morte, a poeta recria a morte-nome, a partir do material vocabular "perecível" de que dispõe, atribuindo-lhe novas nomenclaturas e tornando-a, assim, mais atraente. Por meio de atributos imagéticos, sonoros, sensíveis e intelectivos, fornecidos pelos substantivos ou adjetivos substantivados, o eu-lírico funda uma morte poética, na qual as palavras vão se aproximando por "amor" de suas parecenças e se aglutinando melopaicamente (fulva/feixe/flauta). Nesses versos monossilábicos, a morte adquire um ritmo dançante que a sensualiza e a destitui do significante morte, eliminando, assim, o temor contido na construção anagramática.

Entretanto, ao longo da composição, cria-se um movimento erotizante de aproximação e afastamento que leva à inversão de papéis: ao invés de ser tomada pela morte, a poeta toma-a sensorialmente: se pensá-la lhe é possível em vida, senti-la é condição imposta pelo morrer:

"Se eu soubesse / Teu nome verdadeiro Te tomaria / Úmida, tênue" (XIX, p. 47) 
O verso inquiridor "por que não?" mantém acesa a proposta do encontro, ou ainda, da fusão entre o conhecido e o desconhecido:

"Que eu te conheça lícita, terrena" (II, p. 30)

"Há milênios te sei / E nunca te conheço." (III, p.

31)

E trazendo a Morte para perto de si, o eu-poético desfia infinitas redes de significação, as quais vão se avolumando no poema, desagregando o conceito convencional da imagem-Morte:

"Te batizo Ventura (...) / Te batizo Prisma, Púrpura (...)

Te batizo Riso / Rosto de ninguém

Sonido / Altura" (XXIII, p. 51)

Como se vê, a perseguição ao sublime pela via do erótico, encontra-se fadada ao fracasso de "re-nomear" o que não cabe numa palavra. Como a verdade não se força aos olhos, a poesia não revela numa palavra toda sua verdade: a morte se mostra na potência da língua que, conforme Alain Badiou em seu Pequeno Manual de Inestética, é impotente para lhe dizer, mas que fixa nesse campo magnético-textual, entre o dito e o não-dito, sua essencialidade.

Dessa forma, para se aproximar da Morte, o eu-lírico desenhalhe um corpo físico traçando uma imagem que separe o ser da morte de seu infinito possível: Cavalinha, Cavalo, Búfalo e, principalmente, Cobra. A imagem da cobra aparece nos estudos de Valéry, apontados por Augusto de Campos em Valéry: a serpente e o pensar, associada ao "ícone do pensar": a serpente pelo aspecto espiralado e pela formação em nós representa o pensamento em movimento. Bem por isso, na plasticidade dos poemas que compõem $\mathrm{Da}$ morte..., construída por meio da fanopéia, cristaliza-se a serpente valeriana esgueirando-se em contínuos retornos e metamorfoses e provocando na memória as reminiscências de um passado bíblico.

Essa imagem erótica serpenteia pelos diversos livros da autora, ora associada à morte, ora à própria palavra poética, duas faces do mesmo ser desejoso do Outro:

"Vem dos vales a voz. Do poço. / Dos penhascos. Vem funda e fria (...) / E sibilante e lisa / Se faz paixão, serpente, e nos habita." (Do Desejo, 2004, p. 31)

Chegar à morte é ter o conhecimento, ou seja, a via de acesso ao 
uno. Como que repetindo a função bíblico-inaugural de detentora do conhecimento (sophia), a serpente (ophis) relaciona-se com o proibido e a sua transgressão: com a procura do eu-poético pelo êxtase sagrado nas espirais labirínticas do erótico. Todavia, mais do que símbolo, a serpente se desenha iconicamente, serpenteando em especulações com suas idas e vindas frenéticas. Inscrita nas curvas dessa serpent-penser, o ser mutante morte é sensualmente corporificado para, através da fusão dos corpos, reconciliar espírito e matéria, razão e sensação:

"Duas fortes mulheres / Na sua dura hora." ( I I , p.30)

"Juntas. Tu e eu. (...) / Dois cortes.

Duas façanhas. / E uma só pessoa" p. 58)

(XXX,

Nesta cópula imagética acontece o gozo do texto, o transbordamento da própria poesia. Apenas no breve momento entre os movimentos de contração e expansão da palavra, ou ainda, no momento da apreensão do texto poético, é que há a visão do invisível e intui-se o nome do inominável. Nome esse impronunciável, mas existindo enquanto potência, como se observa em Cantares (2002):

Eu amo o Homem-luz / Que há em mim.

É poeira e paixão / E acredita. //

Amo-te, meu ódio-amor / Animal-vida. (...) (Canto XXIII, p. 56)

Ao justapor duas imagens, como numa cópula metafórica, criase uma fórmula que preserva as imagens evocadas, mantendo-as sem, contudo, sê-las propriamente. Trata-se, pois, de uma potencialidade nascida da união de dois diferentes. Esse procedimento protege a imagem ícone, funcionando como um campo de força contra sua saturação, mantendo sua indizibilidade e, portanto, sua sacralidade.

Sabe-se que o contínuo movimento é característico do signo lingüístico em busca da completude, sua progressão e regressão infinitas participam da continuidade do processo. Nesse sentido, a cápsula metafórica potencializa o devir lingüístico, funcionando como microestrutura da gênese poética. Mais: a cápsula metafórica revela uma faceta dessa representação poética, ou seja, a mobilidade do poema elimina qualquer definição de início ou fim absolutos, indo ao encontro, justamente, da idéia predominante sobre Deus.

Como a atração imagética não possibilita um nome, tem-se um conhecimento verticalizado proposto na relação. O inominável insiste 
em se materializar como ausência ou silêncio, num conceito virtualizado no poema que remete sempre à origem de si mesmo, comprovando o que diz Bataille no seu livro $O$ erotismo, de que a experiência erótica leva ao silêncio. Conclui-se, então, que o fracasso na presentificação do ser é o sucesso da representação poética, que se alimenta desse indizível essencial ao ser humano. As metáforas que se desmetaforizam como atividade reformuladora do pensar/conhecer, ou ainda, a cápsula metafórica que esconde na fusão um "vazio" pronto a "ser", obrigam ao desautomatismo do olhar acostumado com a realidade cotidiana e instauram a experiência do sagrado.

A sucessão de nomes/imagens, cada uma englobando e ampliando a anterior, aponta para uma visão plural e multifacetada do uno num conceito sensível-inteligível que, paradoxalmente, firma sua precisão nesse ambiente impreciso da poesia. Essa impressão faz com que o sagrado continuamente escape-lhe pelos vãos dos dedos. Por isso, a poeta ousa, ainda, atravessar os limites da idéia em favor das exigências sensórias: a busca dos aspectos sensíveis para tornar visível o invisível intensifica-se no volume Poemas malditos, gozosos e devotos (2005):

"É neste mundo que te quero sentir /É o único que sei. O que me resta. / Dizer que vou te conhecer a fundo / Sem as bênçãos da carne, no depois, / Me parece a mim magra promessa. / (...) / Dirás que o humano desejo / Não te percebes as fomes. Sim, meu Senhor, / Te percebo. Mas deixa-me amar a ti, neste texto / Com os enlevos / De uma mulher que só sabe o homem. (VIII, p. 31)

Abre teus olhos, meu Deus, / Come de mim a tua fome. (XVII, p. 53)

Essa postura agressiva intensifica-se ainda mais no volume $D o$ desejo (2004), sendo o sexo reclamado porque se trata do mais primitivo contato do homem com o outro e, por isso, faz-se essencial para tocar o sensível, o inefável:

"Para pensar o Outro, eu deliro ou versejo. / Pensá-LO é gozo. Então não sabes? / INCORPÓREO É O DESEJO” (X, p. 26)

"Extasiada, fodo contigo / Ao invés de ganir diante do Nada"

(I, p. 17) 
O corpo profano torna-se o único lugar possível ao encontro com Deus:

"Olhando o meu passeio / Há um louco sobre o muro / Balançando os pés. / Mostra-me o peito estufado de pêlos / $\mathrm{E}$ tem entre as coxas um lixo de papéis: / - Procura Deus, senhora? Procura Deus? // E simétrico de zelos, balouçante / Dobra-se num salto e desnuda o traseiro." (III, Via Espessa, p. 67)

A imagem do ânus como o "lugar" físico possível para o encontro com a idéia do sagrado é uma constante que reaparece por toda a obra hilstiana e possui grande carga de significação, pois se trata de um corpo "estranho" nas artes poéticas que abala o espaço impreciso do poema. Entretanto, o retorno ao corpo físico desnuda um processo metafísico que não busca extrapolar o corpóreo, mas inscrever-se nele mesmo, reforçando-o através de signos "proibidos". Assim, o lugar mais recôndito do corpo é o espaço mais promissor para a construção do conhecimento, já que se trata do que há de material mais imediato ao homem.

Apesar disso, a palavra pornográfica causa estranhamento, afinal, a poeta quebra com o princípio erótico da poesia, defendido por Roland Barthes em O prazer do Texto: o de não revelar, mas ocultar. Essa pornografia lingüística, por sua vez, leva à perda da aura de mistério, a qual coincide com a implosão significativa. Mas, a auto-revelação no poema, ou o pornográfico, ao expor o que deve estar oculto, leva à mudez da palavra e, portanto, novamente ao silêncio.

Como se percebe, na arena poética hilstiana expõe-se a impotência da palavra em dizer o todo. A verdade poética não está no que se fala, mas no que se cala no poema, e que traduz a dialética do procedimento metafísico que é a ânsia de perseguir o abstrato no concreto: "coisificação dos conceitos através dos sentidos" segundo Augusto de Campos em Verso, Reverso, Controverso.

O contato primitivo e carnal com o corpo físico-textual, escancarado em termos considerados marginais na poesia, tem intenção fundadora de linguagem. Linguagem inaugural fundada/fundida ao corpo como via de acesso ao conhecimento do mundo e ao encontro com Deus e alimentada por esse indizível essencial ao ser humano. 


\section{Do religioso: Adélia Prado e a poética da comunhão}

Um dos primeiros textos críticos sobre a poesia de Adélia Prado é de Carlos Drummond de Andrade que, mesmo um ano antes da publicação do livro de estréia Bagagem, apontou, no artigo "De animais, santo e gente" no Jornal do Brasil, relações entre poesia e religiosidade: "Adélia é lírica, bíblica, existencial, faz poesia como faz bom tempo: esta é a lei, não dos homens, mas de Deus“. Os adjetivos definem um jeito próprio de fazer poesia e qualificam a obra da autora como sendo de um lirismo nascido do ritmo primordial, do canto sálmico, além do pensamento analógico e metalingüístico.

O diálogo entre os universos religioso e poético, presente nos poemas da autora, serão analisados a partir de sua natureza ontológica. Segundo José Ferrater Mora, em seu Diccionario de Filosofia, para Heidegger ontológico 'se refiere al ser', assim a ontologia é "aquella indagación que se ocupa del ser en cuanto ser, pero no como una mera entidad formal, ni como una existencia, sino como aquello que hace posibles las existencias" (1981, p. 2423-25). Como se constata, a experiência poética e a religiosa aproximam-se pela natureza ontológica, entretanto, é preciso ressaltar que a obra de arte literária tem, para Wellek \& Warren no livro Teoria da literatura e metodologia dos estudos literários, "sua própria condição ontológica" (2003, p. 200). Isso implica um tratamento metodológico também específico, que leve em conta: 1) sonoridade, 2) estrutura, 3) imagem e metáfora e 4) o "mito poético" (p. 201).

Assim, tratamos por natureza ontológica, a potencialidade de ser que há tanto na palavra poética, quanto nos ritos religiosos, em especial nos sacramentos. Conforme Mircea Eliade, em $O$ sagrado e o profano, "o homem religioso é sedento do ser" (1996, p. 60) e essa sede ontológica manifesta-se na vontade de situar-se no coração do real, seja recuperando-lhe a essência original pela proximidade com os deuses, seja reinventado-lhe para alimentar sua "substância ôntica", sua "sede de ser". Eis o porquê dos adjetivos "bíblica" e "existencial" aparecerem lado a lado no artigo de Drummond, já que essa poesia revela o real sob um olhar calcado na existência poética das coisas, ou seja, na pulsação de sentidos que se escondem por trás de cada vocábulo, verso ou enunciado poético.

Pode-se afirmar, portanto, que a poética adeliana dialoga com 
o conceito de religare, aqui chamado de comunhão, e com os de imanência e transcendência a ele relacionados por meio de três elementos composicionais presentes em sua obra: metalinguagem, metáfora e ritmo.

A primeira forma de comunhão metafórica ocorre mediante a combinação de "invenção e engenho". (VICO, 1999, p. 211). Esse peculiar engenho criativo, segundo o filósofo Giambattista Vico em Princípios de uma Ciência Nova, tem origem na fantasia que, nada mais é, do que "a memória dilatada" que relembra, fantasia, altera e falseia para depois, com engenho, aplainar, acomodar e ordenar. Nos versos do poema "Para o Zé", em Bagagem (1986) Adélia revela: "o que a memória ama fica eterno", ou seja, a "memória dilatada" torna-se imperecível quando traduzida em palavra poética.

Muitos de seus poemas são estruturados a partir de um pensamento metafórico que revela experiências guardadas na memória em expansão no poema, ao mesmo tempo em que oculta outras, realizando uma apreensão parcial da realidade na reinvenção poética. Num pensamento metafórico assim estruturado, o significado constrói-se também no intervalo entre o dito e o não-dito, espaço de revelação. Afinal, o movimento da memória que se dilata, exige um tempo/espaço de acomodação para, depois, traduzir-se em forma de palavra.

Não se trata, portanto, do uso da metáfora como mero recurso de linguagem que substitui um termo por outro, mas da estruturação do enunciado poético a partir de um modo de pensar metafórico. Isso se torna possível porque seus poemas funcionam no que Paul Ricouer, no livro Da metáfora, chama de "campo associativo": "espaço que permite deslizamentos e substituições" para preencher lacunas autênticas e dar "livre curso às emoções". (p. 185). É o que se verifica no poema "Atávica", Bagagem (1986):

Minha mãe me dava o peito e eu escutava / o ouvido colado à fonte dos seus suspiros: / 'Ó meu Deus, meu Jesus, misericórdia'. / Comia leite e culpa de estar alegre quando fico. / Se ficasse na roça ia ser carpideira, puxadeira de terço, / cantadeira, o que na vida é beleza sem esfuziamentos, / as tristezas maravilhosas. / Mas eu vim pra cidade fazer versos tão tristes / que dão gosto, meu Jesus misericórdia. / Por prazer da tristeza eu vivo alegre. (1991, p. 45) 
A palavra "atávica" é relativa a atavismo: reaparição em um descendente de caracteres de ascendente remoto que permaneceram latentes por várias gerações. Esse significado literal é explorado metaforicamente no texto: o canto que toma forma nos suspiros da mãe, no choro das carpideiras, na ladainha das puxadeiras de terço e nas cantadeiras, reaparece na filha, artesã da palavra. O elemento remoto e latente é a poeticidade presente em ambas as tarefas sob a mesma forma triste ("beleza sem esfuziamentos / tristezas maravilhosas") e retomada nos versos da filha que parte para a cidade grande, levando o primeiro alimento e a primeira herança: o leite materno e a culpa de estar alegre, cantando versos.

Note-se que, no poema, o leite é alimento que se come e não que se bebe. Precisa ser mastigado, digerido e transformado, tal como o trabalho do poeta diante de suas memórias, travestidas em palavras. Recordações afetivas que, reelaboradas, revelam e ocultam aspectos de uma realidade para fundar outra.

O poema se faz canto, desde o ouvido colado à fonte dos suspiros maternos, até o roçar da carpideira, da puxadeira e da cantadeira, numa rima interna que remete à sonoridade dos refrões e das ladainhas. Nesse verso, há tanto uma afinidade sonora, quanto semântica, verdadeira síntese da função metafórica na poesia adeliana: presentificar a singularidade das 'coisas', reapresentando poeticamente suas características. A "memória dilatada", portanto, caracteriza a construção do pensamento analógico em "Atávica", pois o canto presente na memória das experiências primordiais reinventa-se em nova expressão: os versos tristes da filha. A partir de então, já não é o mesmo canto. $\mathrm{O}$ ouvido colado à fonte interior emana, em versos, a transcendência da experiência primeira, desdobrada em apreensão poética.

O segundo elemento que compõe a poética de comunhão adeliana é a metalinguagem: instrumento de "indicação" e "revelação", "sacralização" e "dessacralização", "movimento descendente e ascendente", uma vez que, apontando para a essência da palavra, dirige o olhar do leitor para a grandeza do que deseja apreender, num movimento ascendente de sacralização da linguagem. Paralelamente, ao desnudar o modo como toca essa essência, revela a gênese criadora, num movimento descendente de dessacralização da linguagem.

O poema "Explicação de poesia sem ninguém pedir", Bagagem (1986) aponta, desde o título, para essa dessacralização da linguagem, aspecto que será progressivamente confrontado até a revelação maior 
(sacralizadora) presente no último verso:

Um trem-de-ferro é uma coisa mecânica, / Mas atravessa a noite, a madrugada, o dia, / Atravessou minha vida, / Virou só sentimento. (1991, p. 48)

Embora o título do poema anuncie uma explicação de poesia, seus versos trazem justamente a impossibilidade de explicá-la. Como um trem-de-ferro que, apesar de forte, veloz e mecânico, atravessa paisagens suaves e tempos fugidios, a poesia também possui "consistência, rapidez e exatidão", mas, é com "leveza e visibilidade", atestadas por Ítalo Calvino em Seis propostas para o próximo milênio, que atravessa a vida e vira puro sentimento. Consistência, rapidez e exatidão - presentes na metáfora trem-de-ferro=poesia, dialogam entre si e promovem a condensação, responsável pela intensidade da poesia.

A intensidade poética, da mesma forma, também se constrói na consistência e exatidão do discurso, seja semântico, sonoro ou visual. No entanto, esses conceitos não estão relacionados a uma visão exclusivamente racional da realidade, mas aos reflexos do trabalho do poeta em expressar também suas sensações, sentimentos e percepções de modo esteticamente eficiente. Em cada verso do poema uma imagem salta aos olhos do leitor, compondo em movimento, a paisagem desejada com a "leveza" e a "visibilidade".

São a leveza e a visibilidade da paisagem que explicam a poesia e permitem traduzi-la em puro sentimento. Assim, tem-se primeiro "o trem-de-ferro, coisa mecânica" consistente que, maquinando suas engrenagens, dá início à viagem: é como se ouvíssemos o som crescente e progressivamente rarefeito do trem assim que ele inicia seu percurso. Desse verso em diante, o poema adquire maior velocidade e expressa, na enumeração temporal, a visualização do trem percorrendo "a noite, a madrugada, o dia”.

A visualidade "precede ou acompanha a imaginação verbal" (CALVINO, 1994, p. 99), podendo partir tanto da palavra para a imagem visiva, quanto dessa para a expressão verbal e está presente também em uma das propriedades fundamentais do sacramento da eucaristia: "Não é a matéria do pão, mas a palavra pronunciada sobre ele que beneficia a quem o come (...) A palavra se junta ao elemento (material) e advém o sacramento, como se fosse uma palavra que se visibilizasse", diz Bernard Sesboüe em Os sinais da salvação (2005, p. 34). Portanto, a força da palavra pronunciada pelo sacerdote na consagração do pão eucarístico liga-se tanto à massa fecunda, ingrediente fundamental do 
pão, quanto à fé dos fiéis que participam da celebração e comungam o Corpo de Cristo em palavra e espécie. Do mesmo modo, a expressão "só sentimento", assim, isolada no último verso, destaca-se e fortificase, ligando-se à fortaleza da máquina de ferro e à consistência visual e semântica do discurso poético.

Paul Valéry, em Variedades, já afirmava que "um poema é uma máquina de produzir o estado poético através das palavras" e que "o efeito dessa máquina é incerto, pois nada é garantido em matéria de ação sobre nossos espíritos" (1991, p. 217). A imagem de uma máquina é parte dessacralizadora e descendente do poema e explicita o fazer humano do poeta ao extrair do ambiente externo e cotidiano seus principais recursos para alcançar a paisagem poética sacralizadora que extrai da vida o sentimento ascendente.

Ascendência e descendência, imanência e transcendência também estão ligados ao ritmo na poesia: a transcendência está na imanência, assim como a ascendência na descendência. No universo religioso isso se efetiva na presença misteriosa de Cristo na história humana, mesmo após sua ascensão, mediante o Espírito, sobretudo na celebração dos sacramentos, e, no universo poético, concretiza-se na intersecção dos níveis sonoro e semântico e na configuração de ritmos peculiares, como se observa em "Poema Esquisito", Bagagem (1986):

Dói-me a cabeça aos trinta e nove anos. / Não é hábito. É rarissimamente que ela dói. / Ninguém tem culpa. / Meu pai, minha mãe descansaram seus fardos, / não existe mais o modo / de eles terem seus olhos sobre mim. / Mãe, ô mãe, ô pai, meu pai. Onde estão escondidos? / É dentro de mim que eles estão. / Não fiz mausoléu pra eles, pus os dois no chão. / Nasceu lá, porque quis, um pé de saudade roxa, / que abunda nos cemitérios. / Quem plantou foi o vento, a água da chuva. / Quem vai matar é o sol. / Passou finados não fui lá, aniversário também não. / Pra que, se pra chorar qualquer lugar me cabe? / É de tanto lembrá-los que eu não vou. / Ôôôô pai / Ôôôô mãe / Dentro de mim eles respondem / tenazes e duros, / porque o zelo do espírito é sem meiguices: / Ôôôôi fia. (1991, p. 21)

O movimento descendente inicia seu percurso já no título que anuncia a "esquisitice" do poema. Segue-se a dor rara e sem culpa que 
introduz os primeiros versos e se alastra por toda a primeira parte do poema até traduzir-se em "saudade roxa" abundante e explodir em choro contido, expresso nos vocativos: "Mãe, ô mãe, ô pai, meu pai". É um choro soluçado, em "ô" fechado, pontual e insistente, um nó na garganta porque é 'de dentro' que parte não só a voz, mas também os sentimentos, as lembranças e a própria presença: "é dentro de mim que eles estão"; "dentro de mim eles respondem". O canto guardado em cantos recônditos tem vibração diferente daquele canto que ocupa todos os cômodos, em expansão, pronto para sair, típico do louvor. Esse é um canto silencioso, rouco e grave, que quer florescer com o vento e com a água da chuva, mas logo é sufocado pelo excesso de calor do sol, do sentimento queimando os olhos, a garganta e a cabeça: "é de tanto lembrá-los que eu não vou".

A opção de não visitar o cemitério, bem como de não construir mausoléus, optando pelo enterrar ao invés do erigir, é outra tradução do movimento descendente que predomina no poema. Apesar da estaticidade, o clamor persiste, o chamado se prolonga, se intensifica, cresce e impele: "Ôôôô pai" / "Ôôôô mãe". A resposta finalmente vem, "tenaz e dura", zelosa, mas "sem meiguices". "Ôôôôi fia" é a saudaçãoresposta. A súplica é atendida e o chamado desesperador encontra a presença apaziguadora. A integração dos níveis sonoro e semântico acontece aqui de modo "esquisito" como já anunciava o título do poema. A dor e a saudade geram um ritmo de clamor ascendente, em busca de diálogo com a ausência-presente 'dentro' e a resposta, ao invés de provocar exultação, já que efetiva o diálogo desejado, é zelosa, cautelosa, vem do Espírito, e por isso, desce até o mais profundo do ser para restabelecer a ligação interrompida com a morte.

A "esquisitice" está justamente na ruptura da idéia clássica de que a religação se estabelece unicamente mediante um transcender, num movimento contínuo para o alto. No poema: o transcender acontece num movimento contínuo para o alto e de repente para baixo e para dentro, até encontrar a ressonância interior que promove a religação. Ou ainda, como diz Hermógenes Harada em A Oração no mundo secular: desafio e chance: "Falar a partir da ausência quer dizer: suspender todo o dizer-sobre, isto é, não possuir, não ter nada que eu possa dizer-sobre para deixar a ausência mesma falar, entregar-se à fala da ausência" (1972).

Essa ausculta é a própria interioridade, conceito precioso para a compreensão dos poemas-súplica de Adélia Prado: interioridade que 
"não é nem dentro nem fora, mas que é o envolvimento pleno para a abertura" (HARADA, 1972, p. 100). Auscultar é o que faz o religioso ao entregar-se a Deus em oração, estabelecendo um diálogo por ressonância, já que a oração não se resume a um instrumento de expressão para alguém, mas é, antes, "um médium", um tornar-se "permeável e ressonante à presença envolvente" (Idem, p. 96). É preciso auscultar o ritmo do "Poema Esquisito" para que este ressoe significação, pois é justamente a capacidade de ausculta do eu lírico que realiza a religação ou comunhão desejada.

\section{4. ser poético $=$ ser religioso $=$ ser erótico}

Ao longo dessa reflexão, buscamos apontar o transbordamento e arrebatamento próprios das experiências sagrada e erótica materializadas no intervalo entre o dito e o não-dito da construção poética. A sensação indizível de prazer e gozo, de êxtase espiritual e carnal pôde ser apreendida de forma plena pela poesia em procedimentos composicinais como a metalinguagem, a metáfora e o ritmo tanto na poética de Adélia Prado, quanto na de Hilda Hilst.

Assim, os sacramentos de iniciação cristã (batismo e eucaristia) aproximam-se do ritual da cópula e da sedução (serpent-penser) e juntos constituem elementos fundantes do fazer poético que unifica essas experiências: ser poético $=$ ser religioso $=$ ser erótico. A poesia, impossibilitada de apreender a coisa nomeada (seja recorrendo à metalinguagem, à metáfora, ao canto ou ao silêncio, ao nome ou ao movimento) apreende apenas fragmentos, os quais tenta dotar de unidade perseguindo o desejo de cópula/comunhão entre palavra e coisa. No caso da religião, a celebração dos sacramentos (ação litúrgica) ritualiza o desejo de religação com Deus, também numa tentativa de comunhão; no erotismo, a cópula ritualiza o desejo de união com o Outro, através do movimento serpenteante das idéias que fundem palavras e significados tornando palpável os sentidos. 


\section{Referências}

ANDRADE, Carlos D. "De animais, santo e gente". Jornal do Brasil. Rio de Janeiro, 1975.

BADIOU, Alain. Pequeno Manual de Inestética. São Paulo: Estação Liberdade, 2002.

BARTHES, Roland. O prazer do texto. 5. ed. São Paulo: Perspectiva, 1999.

BATAILLE, Georges. O erotismo. São Paulo: Arx, 2004.

CALVINO, Ítalo. Seis propostas para o próximo milênio. São Paulo: Companhia das Letras, 1994.

CAMPOS, Augusto de. Verso, Reverso, Controverso. São Paulo: Perspectiva, 1988.

. Paul Valéry: a serpente e o pensar. São Paulo: Brasiliense, 1984.

ELIADE, Mircea. O sagrado e o profano. São Paulo: Martins Fontes, 1996.

HARADA, Hermógenes; BOFF, Leonardo; SPINDELDREIER, Ademar. A Oração no mundo secular: desafio e chance. Petrópolis: Vozes, 1972.

MORA, José Ferrater. Diccionario de Filosofia. Madri: Alianza Editorial, 1981.

MORAES, Eliane Robert. O corpo impossível. São Paulo: Iluminuras, 2002.

PAZ, Octavio. O arco e a lira. Rio de Janeiro: Nova Fronteira, 1982.

RICOUER, Paul. O processo metafórico como cognição, imaginação e sentimento. In: SACKS, Sheldon (org.). Da Metáfora. São Paulo: Educ/ Campinas: Pontes, 1992, pp. 145-60. 
SESBOÜÉ, Bernard (dir.). Os sinais da Salvação. São Paulo: Loyola, 2005.

VALÉRY, Paul. Variedades. São Paulo: Iluminuras, 1991.

VICO, Giambattista. Princípios de uma Ciência Nova. Rio de Janeiro:

Editora Record, 1999.

WELLEK, René; WARREN, Austin. Teoria da literatura e metodologia dos estudos literários. São Paulo: Martins Fontes, 2003. 